\title{
Fatores socioculturais no ato tradutório: um estudo de caso
}

\section{Sociocultural factors in the translation process: a case study}

\author{
Christiano Titoneli Santana*
}

Abstract: This paper aims to show, in a general way, the translator's role as a negotiator of meaning. In order to do this, Ernest Hemingway's short story, "Old Man at the Bridge", will be translated to exemplify the translation process and the challenges concerning the sociocultural aspects involved in it. The translation process is not considered here as a lexical equivalence, but as a correspondence of meaning.

Keywords: Sociocultural factors; negotiation of meaning; mediator; translator's role.

Resumo: 0 presente artigo objetiva mostrar, de forma geral, o papel do tradutor ao ver-se inserido no papel de negociador de sentido. Para tanto, será traduzido o conto de Ernest Hemingway, "Old Man at the Bridge", como forma de exemplificação do processo tradutório e dos embates quanto a questões socioculturais. Mostrar-se-á 0 processo tradutório não como equivalência lexical, mas como correspondência de sentidos.

Palavras-chave: Fatores socioculturais; negociação de sentido; mediador; papel do tradutor.

\footnotetext{
* Tradutor e revisor textual. Professor substituto da UERJ -FFP em Língua Inglesa e Metodologia e Práticas de Ensino de Língua Inglesa. Email: christiano.tradutor@gmail.com. 


\section{Introdução}

A proposta deste trabalho é de examinar o processo tradutório e 0 papel do tradutor com vistas a aprofundar a análise já apresentada em nosso artigo, publicado anteriormente, Conto Old "Man at the Bridge": da tradução à análise do papel do tradutor como negociador de sentidos (SANTANA 2011). Assim, poder-se-á explanar e exemplificar, por meio de referenciais teóricos, a função do tradutor como negociador de significado e mediador entre culturas com um olhar para os embates da correspondência de sentidos permeada por fatores socioculturais.

Entraremos, portanto, neste mundo da tradução não revestido de couraça para travar uma guerra entre ideologias e conceitos ruminados por tantos teóricos. Ao contrário, apoiar-nos-emos no diálogo entre teoria versus prática com foco nos fatores socioculturais e na reflexão do ato tradutório e de suas implicações, como as incertezas, dúvidas e, decerto, escolhas voltadas ao mundo da língua-meta. Este trabalho não pretende discutir técnicas de tradução ou demonstrar visões filosóficas que discutam o âmbito da fidelidade e infidelidade.

Primeiro, discutir-se-á brevemente a questão do texto original no processo tradutório com diálogo entre definição de literatura e o conceito desta dentro da comunidade cultural. Segundo, serão apresentados os métodos usados no presente trabalho e o estilo de escrita do autor, Ernest Hemingway, assim como os aspectos gerais do presente conto. Terceiro, serão demonstradas a tradução do conto e considerações a respeito das escolhas durante o processo tradutório à luz da negociação de sentido e dos fatores socioculturais no processo tradutório. 


\section{O texto original no processo tradutório: uma visão teórica}

As primeiras perguntas que vêm à mente são: por que a obra literária é vista como algo inalcançável? Como um texto torna-se uma obra literária? Afinal, o que é literatura? Muitas perguntas surgem no processo tradutório. Essa adoração à espiritualidade e à aura da obra chega, por assim dizer, a causar espanto ao tradutor em formação. Como diz SoBRAL (2008), em linhas gerais, o tradutor deve ter conhecimento de linguística, ter contato com a obra, ser capaz de reconhecer, por meio de conceitos teóricos, os aspectos dos textos literários e, por conseguinte, buscar entender o autor, as suas características e o seu "fazer literário". Ademais, conhecer a obra da alta literatura é lê-la, dialogar com ela, tatear os seus contornos e buscar sua ideologia, críticas e "entrelinhas". O ato tradutório em muito se valerá desses conhecimentos abrangentes do tradutor, uma vez que a tradução tornar-se-á uma releitura - uma visitação entre as possibilidades interpretativas.

As três perguntas iniciais do parágrafo anterior levam-nos a uma série de reflexões. Se perguntássemos o que é literatura, receberíamos diversas definições e, em épocas diferentes, distintos pareceres. Podemos ver que enquanto Platão abominava a poesia por considerar "perigosa", Aristóteles a exaltava em forma até de tragédia, para efeito de catarse. E se fizéssemos a mesma pergunta em nossos dias? Certamente, entraria em ebulição a vasta divergência de opinião.

O que nos faz rotular algo como literário? Segundo ARRoj o (2007: 31) “a literatura seria, portanto, uma categoria convencional, criada por uma decisão comunitária", é o que a sociedade acredita ser, pois o conceito de literatura, apesar de sua complexidade, atende, em termos, às expectativas do grupo social de um dado tempo histórico. Conforme afirma FISH (1980), 0 conceito de literatura constrói-se pela decisão, consciente ou não, da comunidade cultural. Essa denominação e convenção acerca da obra literária 
partem de uma série de teorizações, que aponta que é necessário que a obra apresente a tríade (ficção, real e imaginário), possua literariedade, seja capaz de levar o leitor a diversas leituras e caminhos, não esgote o eixo de sua significação e, além disso, possibilite que, a cada leitura, abra-se para 0 leitor um novo pensar, um recomeçar.

Há produções textuais que são denominadas de certo gênero textual devido a circunstâncias mais exteriores do que a fatores inerentes à obra. Para confirmar essa questão de convencionalidade do que seja obra literária, ArRojo (2007) apresenta como exemplo as obras Os Lusíadas, de Camões, e "Quadrilha", de Carlos Drummond. A autora compara-os e aponta que tais textos demonstram características textuais intrínsecas diferentes entre si. Isso mostra que o contexto histórico e cultural nos quais foram produzidos Os Lusíadas e "Quadrilha" não os reconheceriam como poemas, pois se tratava de um outro momento histórico, uma outra visão literária. Em contrapartida, a nossa comunidade cultural, isto é, a comunidade interpretativa atual, assim denominada por FISH (1980), considera Camões e Drummond os maiores poetas da nossa língua vernácula.

Quanto ao processo tradutório e à saga pela luta da fidelidade textual, alguns teóricos levam em consideração a intraduzibilidade de um texto poético. Para Frost (apud ARrojo 2007: 27), “a verdadeira poesia é intraduzível, definindo-se precisamente como aquilo que 'se perde' em qualquer tentativa de tradução". Para VAlérY (apud ARROJO op.cit.), "a qualidade do texto poético é inversamente proporcional à sua traduzibilidade": quanto mais resistente for o texto "aparentemente" poético ao ataque de qualquer transformação formal, menor será o seu grau de poesia.

Para os teóricos acima citados, a tradução é uma produção textual inferior, pois não consegue alcançar a "alma" do texto literário, visto que a conj unção forma e conteúdo não pode ser tocada sem ocasionar prejuízo da significância e valor do original. Eles consideram o texto como um receptáculo de ideias e/ ou características insubstituíveis e distinguíveis. Essa abordagem, 
SANTANA, C.T. - Fatores socioculturais no ato tradutório: um estudo de caso

portanto, remete-nos ao conceito da literariedade da obra literária ou poética definido por LEOPARDI (apud ARROJ o 2007: 29):

As ideias estão contidas e praticamente engastadas nas palavras como pedras preciosas num anel. Elas se incorporam às palavras como a alma ao corpo, de tal modo que constituem um todo. As ideias são, portanto, inseparáveis das palavras e, se se separarem delas, não serão mais as mesmas. Escapam ao nosso intelecto e ao nosso poder de compreensão; tornam-se irreconhecíveis, exatamente o que aconteceria à nossa alma se se separasse de nosso corpo.

Contrária a esse pensamento de inferioridade, a tradução é vista atualmente como um ato de equivalência textual com olhar no diálogo entre a cultura de partida e a de chegada, segundo Munday (2008). Por ter o seu valor social, a tradução contribui para a riqueza da própria língua de chegada, estabelece novas visões e alargaduras linguísticas. Quanto à impossibilidade de tradução, precisamos olhar 0 ato tradutório, além de tantas outras premissas, como uma correspondência de dimensão sociocultural. Isso implica em dizer que os indivíduos constroem "seu sistema de signos, o qual consistirá numa espécie de 'código' para decifração do mundo" (OLIVEIRA 1997: 37), e cabe ao tradutor imergir nesse sistema para estabelecer correspondências de significado entre os dois mundos postos em evidência no ato tradutório.

Isso nos leva a questionar a arbitrariedade da tradução; poderíamos voltar-nos à questão da própria arbitrariedade de cada língua. Segundo o filósofo SchleIERMACHER (2001), no momento em que o interlocutor assimila o discurso do outro e interpreta o conteúdo, podemos dizer que houve, de alguma forma, uma tradução. Isso acaba por colocar em igualdade a tradução com o processo de interpretação e comunicação da língua. Segundo o filósofo, a tradução entendida como comunicação de conhecimentos entre duas línguas é apenas uma modalidade, enquanto a tradução intralíngua seria a comunicação de conhecimentos dentro da mesma língua. Por ser uma questão ampla, o filósofo dedicou-se mais à questão da tradução entre línguas. Vemos 
que a ciência da tradução, assim como é conhecida hoje, trata das implicações da tradução de uma língua para outra.

Com a visão da tradução interlingual, compreendemos que a complexidade implicada no processo tradutório está sendo vista nas últimas décadas de uma nova maneira, isto é, jogam-se por terra ideais positivistas e levam-se em conta fatores de caráter mais humanista, conforme nos mostra ARROJ O (2007: 32):

\begin{abstract}
A partir de uma dessacralização do "original" e dos conceitos tradicionais de autoria e leitura, e da consequente aceitação de que traduzir é inevitavelmente interferir e produzir significados, num contexto em que se começam a reavaliar as relações tradicionalmente estabelecidas entre teoria e prática e ao abandonar a perseguição inócua da leitura desvinculada da história e suas circunstâncias, a reflexão sobre tradução sai das margens dos estudos linguísticos, literários e filosóficos que sempre buscaram a repetição do mesmo e o algoritmo infalível da tradução perfeita e assume um lugar de destaque no pensamento contemporâneo filiado à pós-modernidade.
\end{abstract}

Não se pode desvincular o texto da história de uma comunidade interpretativa e dos seus aspectos socioculturais. É preciso entender que o ser humano, segundo VYGOTSKY (1978), é mediado por artefatos culturais, atividades e conceitos. São estes que delineiam o texto-fonte e o texto-meta; o próprio texto original sofre influência do tempo, pois, como afirma BENJ AMIN (2008), o tipo de linguagem que foi tendência na época de um determinado autor pode ter desaparecido e ressurgido sob nova forma. A obra literária transforma-se no decorrer do tempo, pois é também produto de um momento histórico.

A denominação do que seja "literário" é fruto de certo convencionalismo amparado por cada comunidade cultural. Aceitar a intraduzibilidade de uma obra original e trancafiar-se na eterna questão da fidelidade significa não entender a mudança da própria língua, das nuances culturais e, principalmente, do conceito de tradução. Nenhum texto escrito, em determinada época, permanece com a mesma carga significativa e 
SANTANA, C.T. - Fatores socioculturais no ato tradutório: um estudo de caso

totalmente inteligível nas gerações subsequentes. BENJAMIN (2008: 87) afirma que "aquilo que antes era novo pode depois soar a gasto, o que antes era corrente pode mais tarde ter ressonâncias arcaicas". Ele ainda complementa dizendo que "se o tom e a significação dos grandes textos se alteram totalmente no decorrer dos séculos, também a língua materna do tradutor muda" (op.cit. 2008: 87). Sendo assim, a língua tanto da obra original quanto da tradução muda com o passar do tempo, e alguns aspectos lexicais ou pontos de inferência histórica nas obras podem não perpetuar e, fatalmente, não alcançar o leitor de uma época posterior.

Traduzir não é transferir significados de uma língua para outra, pois as palavras não têm significados estáveis e enrijecidos, elas residem no mundo do "estar", e não do "ser". Elas desempenham um papel segundo o seu contexto e a leitura do tradutor. Sendo a palavra transmutável tanto na língua do texto original como da língua-alvo, ARROJ O (2007) considera o texto original como um palimpsesto - uma espécie de pergaminho ou papiro cujo manuscrito era raspado, devido à escassez ou alto preço, para ser substituído por um novo texto. Metaforicamente, ARROJ o (2007) afirma que o texto original se apaga para dar lugar à outra leitura, interpretação do "mesmo" texto em época e comunidade cultural diferentes.

Querer trazer as características da obra original em sua "totalidade" é pura utopia, transcende a ideia e a função da tradução. Buscamos, hoje, entender que a tradução traz implicitamente a leitura, as influências socioculturais do tradutor, pois também a obra original não se finda nela mesma, sua interpretabilidade é multifacetada. O texto, uma vez escrito, ganha vida e passa a ser não do autor, mas de todos os leitores. A obra, então, apresenta várias leituras com base no tema central do autor. Por isso, seria impossível existir tradução se a considerássemos como transferência de significados estáveis. 0 que acontece, a todo o momento, no ato tradutório é, segundo DERRIDA (1978: 30), "uma transformação: uma transformação de uma língua em outra, de um texto em outro". Mas se vemos a tradução como um processo de transformação, então como poderemos avaliar a qualidade de uma tradução? 
Por meio de uma ilustração, ARRojo (2007) relata como seria essa avaliação. Ela explica que se houvesse um concurso de fantasia para eleger a candidata mais parecida com a rainha Cleópatra, a banca de jurados escolheria a mais "fiel" à Cleópatra "original". Porém, mesmo tendo pesquisado, estudado a fundo os costumes para confeccionar a roupa, cada candidata levaria, de forma implícita, a marca e a influência de sua própria época e localização ao vestir-se e comportar-se como a rainha Cleópatra. E de que forma os jurados decidiriam quanto à "verdadeira" ou "original" versão da rainha? A decisão seria feita segundo o conjunto de suposições e características que os jurados, segundo a comunidade cultural, considerariam como verdadeira. Entretanto, temos de levar em conta a questão contextual, em outras palavras, uma versão de Cleópatra que é considerada "original", por exemplo, no início do século XX em uma dada cidade, a mesma versão, olhada por foto, pode não ser aceita como "original" pela comunidade interpretativa da mesma cidade 80 anos depois.

Por isso, traduzir, por exemplo, uma obra literária, é ser fiel à concepção vigente de obra literária. Em linhas gerais, nossa tradução não será fiel ao texto "original", mas ao que consideramos ser o texto original, ao que nomeamos ser o texto "original". Portanto, a tradução não deixa de ser fruto do que somos como comunidade interpretativa, sentimos e pensamos.

Somos fiéis, de alguma forma, às concepções e teorias da comunidade interpretativa. Muitas vezes, deleitamo-nos com a tradução que julgamos e consideramos como "fiel" e descartamos visões e pareceres que não acreditamos, pois não fazem parte da convenção de nossa sociedade. Sendo assim, é impossível rotularmos uma tradução ou leitura de um texto como única e verdadeira para todas as épocas e todos os lugares. A língua muda, a sociedade muda - o texto original com sua essência permanece, mas a leitura e interpretação sempre se transformam. 
SANTANA, C.T. - Fatores socioculturais no ato tradutório: um estudo de caso

\subsection{0 conto "Old Man at the Bridge"}

O conto narra a história de um soldado que, em meio à ação militar, encontra um senhor próximo à ponte onde várias pessoas estão passando para escapar da zona de guerra. 0 soldado tenta convencer aquele velho homem a sair e atravessar a ponte, mas percebe que 0 velho ficará ali até a morte. 0 narrador é em primeira pessoa, e é quem descreve em minúcias o diálogo entre os dois, apresenta os comentários reveladores do senhor. A consciência do narrador quanto à vinda do inimigo cria uma tensão entre a imobilidade do senhor e a destruição já anunciada. Toda essa ação é descrita pelo narrador ao comentar o movimento das carroças passando pela ponte. Durante a conversa, o narrador dá voz ao idoso. Enquanto ele conversa com o soldado, nós, leitores, juntos com o soldado, aos poucos, vamos entendendo o grande dilema daquele velho homem e o que a guerra fez com ele. Vê-se que as vítimas sem voz e sem vez se expressam por intermédio desse senhor, assim não é mais o senhor falando, é o povo externando a sua história, dor e angústia.

O contexto sociocultural emana da realidade vivenciada por Hemingway e reflete no conto. Para compreender o âmbito de produção do presente conto, é preciso entender que a história carrega experiências vividas por Hemingway como jornalista, segundo nos informa TYLER (2001). Inicialmente, esta história era um noticiário que se transformou em conto. Mesmo a brevidade sendo seu maior estilo, esta obra traz a guerra como pano de fundo sociocultural.

Como Olivelra (1997: 21) afirma, "a relação homem/mundo é uma relação mediada por sistemas simbólicos", também permeados pelo fator histórico. Torna-se evidente na obra original a relação de Hemingway com 0 contexto histórico da Guerra Civil Espanhola. Esse sistema simbólico é mediado pela linguagem militar, pelo conhecimento do autor a respeito das guerras que presenciou em conjunto com seu estilo de escrita. Ler o presente conto é também ver, implicitamente, o conflito entre os nacionalistas e os 
republicanos e a luta do general Franco para estabelecer sua ditadura fascista. Segundo WALDHORN (2002), Hemingway escreveu a agonia da guerra, com uma visão aguçada e, ao mesmo tempo, sensível; a guerra era o que Hemingway melhor noticiava.

Se formos pensar o texto original deste conto no processo tradutório, devemos ol har para o momento histórico, os fatores socioculturais, o perfil do autor enquanto jornalista, ou seja, todo aparato implícito e produto de um meio social. Portanto, o texto original não se resume apenas ao estilo de escrita ou sua influência literária, mas também ao grupo social e à historicidade que cerca o autor.

\section{Procedimentos Metodológicos}

O corpus do presente artigo é composto pelo conto "Old Man at the Bridge". A análise e discussão estão embasadas na teoria da tradução de Rosemary Arrojo, sob o título Oficina de Tradução, e do teórico Adail Sobral, sob a obra Dizer o 'Mesmo' a Outros: Ensaios sobre Tradução. Quanto às perspectivas socioculturais, estas estão fundamentadas nos princípios de Lev Vygotsky, em sua obra Mind in society: the development of higher psychological processes.

A tradução foi feita pelo autor do presente artigo, que buscou, por meio do fazer tradutório, relatar alguns dos potenciais embates no processo de tradução tendo como pano de fundo a questão sociocultural apresentada por VYGOTSKY (1978).

Nesta seção, seguiremos com uma breve explanação sobre o estilo do autor Ernest Hemingway, estabelecendo um diálogo com o conto trabalhado. Na seção 4, será apresentada a tradução e, a seguir, sua análise à luz dos estudos da tradução e dos fatores socioculturais entrelaçados no ato tradutório. 


\subsection{Ernest Hemingway: estilo de escrita}

Hemingway é conhecido por ser objetivo e criar cenas e símbolos dentro da história em poucas palavras. Isso para o tradutor é um desafio, pois é preciso atender à brevidade do autor e, ao mesmo tempo, à linguagem também jornalística arraigada pelo jargão militar.

Seu estilo de escrita é enfático na objetividade por meio de frases declarativas simples, segundo KIDD (1971). Com a economia das palavras, o autor consegue expressar sua visão de experiência com muita disciplina, conforme nos é dito por WALDHORN (2002). Muito da realidade era incorporada à sua prática literária, pois sua prosa comunicava "a emoção da realidade" (WALDHORN 2002: 31). Definitivamente, são as frases curtas que tornam a obra intrigante, levando o leitor à curiosidade e especulação.

De acordo com LOPES (2012), o efeito do seu trabalho era impactante, pois ele escrevia sobre assuntos os quais dominava. Isso obriga o leitor a ler as entrelinhas por seus contos possuírem a característica da autenticidade misturada a "sensações cinéticas que transmitem uma forte noção do realismo ao leitor" (LOPES 2012: 19). Portanto, pensar realismo em sua obra é considerar 0 ato tradutório como uma prática que busca compreender os fatores socioculturais da língua-fonte e entender o grupo social da línguameta, para então encontrar caminhos para a tradução.

\section{Da tradução à análise: "Old Man at the Bridge"}

$\underline{\text { Um velho senhor na ponte }}$

Um velho senhor, usando óculos de armação de aço e roupas muito sujas, sentou-se à beira da estrada. Havia uma ponte flutuante que cruzava 0 rio, e por ela passavam carroças, caminhões, homens, mulheres e crianças. As 
carroças, movidas por mulas, sacolejavam ao subir a ribanceira após atravessar a ponte, com a ajuda dos soldados que as empurravam pelos raios das rodas. Deixando tudo para trás, os caminhões seguiam caminho com muita dificuldade, e os camponeses, com os tornozelos cobertos de poeira, mal conseguiam andar. Mas lá estava o velho senhor sentado sem se mexer; cansado, não conseguia dar nenhum só passo.

O meu dever era atravessar a ponte, ir até o outro lado e saber a que altura avançava o inimigo. Depois, voltava ao início da ponte. Já quase não havia mais carroças e pessoas a pé, mas o velho senhor ainda ali permanecia.

"De onde vem o senhor?", perguntei-Ihe.

"De San Carlos", respondeu, dando um sorriso.

Era sua terra natal, ele sorriu e demonstrou orgulho ao dizer o nome da cidade.

"Eu tava tomando conta dos animais", explicou ele.

"Ah, sim", respondi, sem entender muito.

"Pois é", disse ele, "eu tava tomando conta dos animais. Fui o último a sair da cidade de San Carlos".

Ele não parecia ser nem pastor nem boiadeiro, olhei para aquela roupa encardida de poeira, para seu rosto todo empoeirado e para aqueles óculos de armação de aço e, então, perguntei: "Que tipo de animais eram?"

"Vários", disse ele, balançando a cabeça, com tristeza. "Eu tive que deixar eles pra trás".

Fiquei olhando a ponte, a cidade do Delta do Ebro, que mais parecia a África, e me perguntei quanto tempo mais restaria para o inimigo chegar, e permaneci atento a qualquer barulho que sinalizasse o acontecimento tão misterioso chamado contato, e o velho senhor continuava ali sentado.

"Que tipo de animais eram esses?", voltei a perguntar.

"Eram três no total", explicou ele. "Eram duas cabras e um gato, tirando os quatro casais de pombos".

“Então o senhor teve que abandonar eles?", perguntei. 
SANTANA, C.T. - Fatores socioculturais no ato tradutório: um estudo de caso

“É. Foi por causa da artilharia. O capitão me disse pra ir embora por causa da artilharia".

"Você não tem família não?, perguntei, olhando para o outro lado da ponte, onde ainda algumas carroças apressavam-se para descer a ribanceira.

"Não", respondeu ele, "só os animais que eu disse. O gato, sem dúvida, vai ficar bem. 0 gato sabe se cuidar muito bem, mas não sei o que será dos demais".

"O senhor gosta de política?", perguntei-Ihe.

"Não entendo nada de política", respondeu. "Estou com setenta e seis anos. Já andei doze quilômetros, nem sei se consigo dar um passo a mais".

"Aqui não é um bom lugar pra se parar", disse eu. "Se quer mesmo sair daqui, tem uns caminhões um pouco mais adiante dessa estrada que estão indo pra Tortosa".

"Vou ficar mais um pouco", comentou ele, "e depois eu vou. Pra onde os caminhões vão mesmo?"

"Pra Barcelona", respondi.

"Não conheço ninguém que vai pra lá", disse ele, "mas muito obrigado. Obrigado mesmo".

Com uma expressão de vazio e cansaço, ele olhou para mim e disse, como se quisesse dividir sua preocupação comigo: "O gato vai ficar bem, tenho certeza. Não preciso me preocupar com o gato, mas o resto? 0 que você acha que vai acontecer com os outros, hã?"

"Olha, tudo indica que eles se sairão bem dessa".

"Acha mesmo?"

"Por que não?", disse eu, olhando para o final da ponte, onde não se via nem mais carroças.

"Como esses animais vão se proteger de tanta artilharia, já que me mandaram sair correndo de lá?"

"O senhor deixou a gaiola aberta pra as pombas saírem?", pergunteiIhe.

"Claro."

"Ah, então elas voarão pra bem longe." 
"Tomara! Mas os outros. Acho melhor nem pensar muito nisso", disse ele.

"Se o senhor já descansou, é melhor ir. Eu iria", insisti. "Levante, tente ficar de pé".

"Obrigado", disse ele, levantou-se cambaleando e caiu para trás em meio àquela poeira.

"Eu tava tomando conta dos animais", disse ele, totalmente apático e sozinho. "Eu só tava tomando conta dos animais".

Não havia mais nada a se fazer. Era domingo de Páscoa, e os fascistas avançavam em direção ao Ebro. Nesse dia, o céu estava muito escuro e as nuvens baixas impediam que os aviões subissem aos céus. Essa situação e 0 caso dos gatos foram a única coisa boa que Ihe restava.

\subsection{Análise do processo tradutório sob 0 prisma sociocultural}

Esta análise pretende abarcar alguns pontos críticos (que estarão em negrito e itálico) no processo de tradução e, em seguida, argumentar a respeito do papel do tradutor face aos fatores socioculturais da obra original e ao estilo de escrita do autor. Com a finalidade de melhor entendimento, serão apresentados alguns parágrafos da obra original com os respectivos parágrafos de nossa proposta de tradução, conforme disponibilizada na seção anterior.

De forma alguma, tem-se a pretensão de apresentar a tradução como modelo, mas como um meio de analisarmos a obra à luz dos aspectos sociais, históricos e culturais em relação ao papel da reprodução, negociação e ressignificação de sentidos entre culturas. 
SANTANA, C.T. - Fatores socioculturais no ato tradutório:

um estudo de caso

(I)

\begin{tabular}{|c|}
\hline \begin{tabular}{c|} 
Texto original \\
(?) Old Man at the Bridge
\end{tabular} \\
\hline$\frac{\text { Tradução proposta }}{\text { Um velho senhor na ponte }}$ \\
\hline
\end{tabular}

Primeiramente, precisamos verificar esse cuidado do autor ao não colocar o artigo the no início do título. Temos de observar que ele, nesse caso, generaliza o homem, dando um aspecto mais universal. Porém, no processo tradutório, o tradutor encontra esta primeira questão que, portanto, deve ser pensada e estudada durante o conto, para, no fim da tradução, levar ao leitor um título que atenda à proposta do original. Após traduzir o conto e revisá-lo, pensamos na hipótese de acrescentar o artigo indefinido um ao título. Se tentássemos ser fiéis ao texto-fonte, não levando em conta a formação de sentidos e o âmbito sociocultural, o título ficaria da seguinte forma: Velho na ponte. Além de apresentar um truncamento na tradução, evidencia-se que não foi avaliada a natureza estrutural da língua-alvo. Conforme diz SOBRAL (2008):

Ao traduzir, o tradutor procura entender o que é expresso numa língua, considerando quem diz o quê, como, onde, quando e, principalmente, com que intenção e no âmbito de que cultura, e procura fazer isso ser entendido em outra língua, levando em conta quem diz o quê, como, onde, quando e, principalmente, com que intenção e no âmbito de que cultura.

Portanto, o acréscimo do artigo traz ao leitor a quebra do estranhamento rítmico do título, atribuindo a este o sentido generalista do ser humano que o autor quis provocar. Além disso, há implicitamente o valor social retratado por meio da generalização, que sugere o sofrimento do povo ao sair de suas cidades devido à Guerra Civil Espanhola. 
(II)

\section{Texto original}

An old man with steel rimmed spectacles and very dusty clothes sat by the side of the road. There was a pontoon bridge across the river and carts, trucks, and men, women and children were crossing it.

\section{Tradução proposta}

Um velho senhor, usando óculos de armação de aço e roupas muito sujas, sentou-se à beira da estrada. Havia uma ponte flutuante que cruzava o rio, e por ela passavam carroças, caminhões, homens, mulheres e crianças.

Nessa passagem, o tradutor depara-se com as palavras pontoon bridge que a tradução equivalente seria pontão. 0 dicionário Aulete on-line apresenta a seguinte definição: "Plataforma flutuante que serve de ponte ou que, junto com outras, forma uma ponte". O papel do tradutor é avaliar 0 peso contextual da palavra na língua-fonte, a produção social na história e examinar a questão da correspondência de sentido para a língua-alvo. 0 tradutor deve indagar-se: "Será que ao colocar a palavra pontão estarei sendo fiel ao texto original e, ao mesmo tempo, a compreensão chegará ao meu leitor-alvo de forma fluida?" Ao examinarmos essa questão, podemos chegar a algumas conclusões. Talvez, manter a palavra pontão seja uma questão meramente de equivalência de palavra, mas não de correspondência cultural e social. Apesar da palavra pontão existir na língua-alvo, não transparece a obj etividade e clareza de Hemingway. Os seus textos têm a simplicidade como critério; a beleza de seu texto implica na crítica e no valor de conhecimento do mundo da guerra que ele deseja passar. Portanto, escolher a palavra pontão na língua portuguesa talvez traga uma falsa felicidade ao tradutor, ao crer que passou a visão do contexto militar que 0 autor desejava transmitir. 0 tradutor se engana, pois o leitor da língua-alvo será capaz de construir a imagem a partir de conceitos que tenham um compromisso maior com 0 aspecto sociocultural. 
SANTANA, C.T. - Fatores socioculturais no ato tradutório: um estudo de caso

Dessa forma, em busca da negociação de sentido de um termo que equilibrasse a linguagem corrente com o uso militar, foram escolhidas as palavras "ponte flutuante" como resultado de um trabalho de pesquisa desses termos em jornais na língua portuguesa, conforme apresentado, a seguir, na manchete do jornal 0 Globo on-line: "Exército termina montagem de ponte flutuante no Pantanal".

No que diz respeito à importância da correspondência cultural e dos fatores socioculturais, SOBRAL (2008: 81) faz a seguinte observação:

Pensar a interpretação como a busca de correspondência [...] implica pensar as línguas não como compostas por elementos equivalentes aos de outras línguas, mas como compostas por formas de expressão que usam esses elementos para criar, no âmbito de uma dada cultura, formada por diferentes expressões, sentidos que a operação de tradução pode fazer corresponder a sentidos criados em outra cultura, igualmente complexa, formas de expressão que não são exatamente iguais nem equivalentes, mas que permitem criar efeitos de sentidos semelhantes.

O uso dos termos ponte flutuante tem uma relação maior de sentido na cultura da língua-fonte do que a palavra pontão. Isso, portanto, significa entender o traço sociocultural da língua-fonte, uma vez que o autor comporta-se como reportador e mediador de um evento histórico. Obviamente, há o valor ficcional que caracteriza a obra como conto, mas os traços da realidade são constantes e claros na produção original. Isso demanda um mesmo perfil na tradução, isto é, o traço da realidade e a brevidade escolhida no original devem ser seguidos também na língua-meta.

(III)

\section{$\underline{\text { Texto original }}$}

"I was taking care of animals," he explained.

\section{Tradução proposta}

"Eu tava tomando conta dos animais", explicou ele. 
O primeiro aspecto que devemos pensar a partir dessa frase não é exatamente 0 entrelaçamento das palavras, mas o traço da linguagem oral. Quando vemos, na tradução, o verbo estar no pretérito perfeito do indicativo estava na sua forma reduzida tava, percebemos um traço da oralidade. Para criar esse traço, é preciso recorrer ao estilo daquele personagem, arguir se a fala do personagem carrega um tom formal ou informal. Essa questão é importante de ser levantada, pois alguns tradutores podem negligenciar esse critério, dando às vezes um tom totalmente formal/artificial à fala do personagem. Nesta tradução, ao pensar na simplicidade do autor do conto, preocupamo-nos em levar essa oralidade na escrita, no intuito de trazer em evidência a fala mais natural de um camponês. O cenário construído é sinônimo de pressa e movimento; entende-se, então, que um diálogo entre duas pessoas, que se conhecem em meio à ebulição de uma guerra, não será de total polidez, uma vez analisado o perfil dos personagens.

Outro aspecto é a questão da padronização da frase. 0 tradutor deve perceber que durante o conto a frase: "Eu tava tomando conta dos animais" repete-se praticamente da mesma forma; portanto, o tradutor deve estar atento à estética da frase, para que ela possa adequar-se em todos os momentos em que aparecer. A padronização é de extrema relevância, pois há um motivo para 0 autor manter a frase e fazer pequenos acréscimos durante sua aparição, fato este comprovado também na última menção da frase: "Eu só tava tomando conta dos animais". O autor acrescenta o advérbio só para dar um efeito de ingenuidade à fala do personagem. Não podemos esquecer também que os animais - o gato, as cabras e, depois, os quatro casais de pombos mencionados, mas não contabilizados - apresentam todo um valor simbólico e sociocultural referente às vítimas da Guerra Civil Espanhola, a saber: o gato é o sobrevivente; os pombos, que no final viram pombas (da paz), fazem parte da ironia construída no contexto, já que as pombas voam para longe; as cabras são citadas à frente como os demais ou os outros e carregam, histórica e simbolicamente, o significado de serem animais para o sacrifício. 
SANTANA, C.T. - Fatores socioculturais no ato tradutório: um estudo de caso

Sendo assim, o tradutor precisa observar e examinar efetivamente os traços do personagem, o cenário e, principalmente, o estilo do autor. Isso reflete 0 fato de que "o tradutor é um mediador-participante, alguém que organiza uma tradução 'interlingual'" (SOBRAL 2008: 91). Esses pontos contribuem para uma tradução com um olhar além da linguagem, voltado mais à questão sociocultural e histórica.

(IV)

\section{$\underline{\text { Texto original }}$}

"What politics have you?" I asked.

"I am without politics," he said.

\section{Tradução proposta}

“O senhor gosta de política?", perguntei-Ihe.

"Não entendo nada de política", respondeu.

Interpretar e ler a obra vinculada à história e ao contexto é uma atividade substancial no processo tradutório. Por vezes, o tradutor, seja pela correria da entrega da tradução da obra ou pela falta de conscientização e preparo, deixa esquecidos fatores sociais, históricos e culturais inerentes à obra. Por isso, traduzir uma obra, independentemente de sua extensão, significa ler, interpretar e buscar informações concernentes à proposta e construção do texto. Tendo como base esses princípios, busquei interrogar-me a respeito da construção da frase na língua original do conto e do seu eixo semântico dentro de seu contexto social.

A palavra-chave politics significa orientação, crença ou opinião política. Se formos tentar aproximar a tradução ao texto-fonte, não levando em conta a questão pragmática da língua-alvo, teremos, entre outras traduções possíveis, a seguinte construção: [pergunta do soldado] "Qual orientação / crença / opinião política você tem?" e [resposta do camponês] "Não tenho orientação / crença / opinião política". Temos, portanto, um exemplo de uma tradução mais aproximada ao texto original. Mas será que 
essa tradução e construção frasal e sua semanticidade retratam a natureza da língua portuguesa? Se pensarmos que o idoso é um simples camponês, que possui uma vida bucólica, e o diálogo entre os dois é breve, veremos que a tradução não é apropriada e é um tanto quanto artificial.

A interpretação no ato tradutório e o estudo sociocultural do texto são o fulcro da inteligibilidade e eficácia de uma tradução. Com isso, buscamos a essência da pergunta feita pelo soldado e a resposta do camponês já de idade. Por um lado, o soldado quis saber se o camponês tinha algum conhecimento político, para averiguar se aquele senhor estava ciente do que estava acontecendo; do outro lado, evidenciam-se a ingenuidade e a falta de conscientização por parte do senhor acerca do acontecimento. Portanto, optamos pelo diálogo: [o soldado pergunta] "O senhor gosta de política?" e [0 senhor responde] "Não entendo nada de política".

0 grande desafio para o tradutor é submergir na essência da obra, para ser capaz de retratar a atmosfera sociocultural no texto-alvo. Sendo assim, esse profissional da palavra corre dois riscos: se adotar o recurso da adaptação estrutural e semântica da frase, poderá haver "uma exploração abusiva da originalidade" (VENUTI 2002: 66); se preferir manter uma tradução dita como tradicional e ética, poderá acontecer de "a intenção autoral não controlar seu significado e seu funcionamento sociais" (VENUTI op.cit.) no contexto da língua-alvo.

(V)

Texto original

It was a gray overcast day with a low ceiling so their planes were not up. That and the fact that cats know how to look after themselves was all the good luck that old man would ever have.

\section{Tradução proposta}

Nesse dia, o céu estava muito escuro e as nuvens baixas impediam que os aviões subissem aos céus. Essa situação e o caso dos gatos foram a única coisa boa que the restava. 
SANTANA, C.T. - Fatores socioculturais no ato tradutório: um estudo de caso

Para encerrarmos esta seção de análise, primeiro olhemos a função do that no exemplo apresentado. 0 pronome demonstrativo that, nesse texto, torna-se um elemento referencial anafórico, ou seja, sua função é retomar o termo referencial da frase anterior para efeito coesivo. Se formos traduzir that como este(a) ou esse(a), de modo a evocar uma mera substituição de palavra, causaremos certo estranhamento e artificialidade no texto. Agora, verifiquemos a frase seguinte: the fact that cats know how to look after themselves [...], a qual literalmente significa: o fato dos gatos saberem se cuidar [...]. A respeito dessa tradução, o tradutor precisa levar em conta que essa informação já foi apresentada no texto e, por sua vez, a repetição dela integralmente não denotaria um efeito enunciativo eficaz, tampouco um efeito linguístico efetivo na língua portuguesa.

Envolvido no universo de escolhas de termos, o tradutor precisa interpretar e, primordialmente, refletir a partir dos elementos textuais da língua-fonte e examinar como poderia manter a intenção enunciativa na língua-alvo. Desse modo, o tradutor deve perceber que se trata não exatamente de uma substituição de palavras, mas sim de uma correspondência de sentido e de amplitude sócio-histórico-cultural. Sabendose disso, o elemento referencial that transformou-se em essa situação, retomando a explicação anterior, e a frase the fact that cats know how to look after themselves [...] transformou-se em o caso dos gatos, assim permanecendo o sentido e a brevidade do autor e, ao mesmo tempo, objetivando um compromisso com o leitor da língua-alvo, pois como afirma RoSENZWEIG (1994: 47) "traduzir é servir a dois senhores: ao estrangeiro em sua obra, ao leitor em seu desejo de aproximação".

\section{Considerações Finais}

Muito se discute a relação do tradutor com a obra original. Este trabalho preocupou-se, particularmente, em mostrar o fazer tradutório como pano de fundo os fatores socioculturais. Este trabalho buscou apresentar 0 ato 
tradutório como um processo reflexivo, que se volta para o leitor de forma a alcançá-lo dentro de sua linguagem e de seu conhecimento histórico e cultural, mas com um ol har voltado aos conceitos socioculturais do contexto de produção original. Isso não significa ruptura com a obra original e muito menos adaptação; trata-se verdadeiramente de romper com as entranhas tradicionais da equivalência lexical e estabelecer a correspondência de sentido, levando de uma língua à outra o valor social contido no mundo da significação e não da substituição de palavra por palavra.

o compromisso não foi apontar erros ou esquivar-se dos problemas também intrínsecos à formação do tradutor, foi frisar que o papel do tradutor face à obra original deve ser interpretado como um ato de grande responsabilidade para com o autor, com o leitor e, principalmente, com a mensagem fruto de um trabalho que permeou o discurso, a linguagem, os aspectos identitários e culturais de uma língua e se reconstruiu em outra.

Portanto, traduzir é ler nas entrelinhas, é entender o contexto que abrange 0 autor; é sentir e estar como leitor, é viver a intensidade da obra, é frustrar-se, é indagar-se; é dizer ao outro aquilo que ouviu como ecos; é satisfazer-se, não se satisfazendo; é escrever, apagar e reescrever; é ouvir e atordoar-se em meio a tantas vozes, mas poder responder somente a uma. Em meio a isso, é importante, por fim, entender os fatores socioculturais da língua-fonte, pois são estes alguns dos responsáveis por delinear o caráter específico do texto.

\section{Referências bibliográficas}

ARROJ 0, R. Oficina de tradução. São Paulo: Ática, 2007.

BENJ AMIN, W. A tarefa do tradutor. Tradução de J oão Barrento. In: BRANCO, Lucia Castello (org.). A tarefa do tradutor: quatro traduções para 0 português. Belo Horizonte: Fale/ UFMG, 2008, p. 82-98.

DERRIDA, J. Positions. Tradução de Alan Bass. Chicago, University of Chicago Press, 1978. 
SANTANA, C.T. - Fatores socioculturais no ato tradutório:

um estudo de caso

FISH, S. Is there a text in this class?; the authority of interpretive communities. Cambridge, Harvard University Press, 1980.

HEMINGWAY, E. "The Old Man at the Bridge." The Short Stories of Ernest Hemingway. New York: Macmillan, 1986. Pp. 78-80.

KIDD, W.E. (1971) "Introdução". In: W.G. FRENCH, \& W.E. KIDD (Eds.), A Literatura Americana e o Prêmio Nobel, São Paulo: Editora Cultrix.

LOPES, I.M.E.F.O. Tradução de contos de Ernest Heminway. Tese de Doutorado. Porto: Universidade do Porto, 2012.

MUNDAY, J. Introducing Translation Studies: Theories and Applications, 3rd Edition. London and New York: Routledge, 2008.

OLIVEIRA, K. M. Vygostky: aprendizado e desenvolvimento: processo sóciohistórico. São Paulo: Scipione, 1997.

ROSENZWEIG, F. Scripture and Luther. In: BUBER, Martin, ROSENZWEIG, Franz. Scripture and translation. Trad. Lawrence Rosenwald, Everett Fox. Bloomington: Indiana University Press, 1994, p. 47-69.

SANTANA, T. C. Conto Old Man at the Bridge: da Tradução à Análise do Papel do Tradutor como Negociador de Sentidos. In: Revista Litteris, oㅡ 8, 2011, pp.152-165.

SCHLEIERMACHER, F. Sobre os diferentes métodos de tradução. In: HEIDERMANN, W. (Org.). Clássicos da teoria da tradução. (Tradução de Margarete Von Mühlen Poll). Florianópolis: UFSC, Núcleo de tradução, 2001. v1, p. 27-28.

SOBRAL, A. Dizer o 'Mesmo' a Outros: Ensaios sobre Tradução. São Paulo: Special Book Services, 2008.

STEINER, G. After babel; aspects of language and translation. Oxford, Oxford University Press, 1975.

TYLER, L. Student Companion to Ernest Hemingway. Westport: Greenwood Publisginh Group, 2001.

VENUTI, L. Escândalos da tradução. Bauru: Edusc, 2002.

VYGOTSKY, L.S. Mind in society: the development of higher psychological processes. Cambridge, MA: Harvard University Press, 1978.

WALDHORN, A. A reader's guide to Ernest Hemingway. New York: First Syracuse University Press Ed., 2002.

«ttp://aulete.uol.com.br>. Dicionário Aulete on-line. Acesso em: 31 de maio, 2011.

বhttp:/ / oglobo. globo. com/ cidades/ mat/ 2011/ 04/ 18/ exercito-terminamontagem-de-ponte-flutuante-no-pantanal-924264532.asp>. O Globo On-line Cidades. Publicado em: 18/04/2011. Acesso em: 31 de maio, 2011. 